\title{
Inquiries into the role of economics in Canadian forestry ${ }^{1}$
}

\author{
by M. K. (Marty) Luckert²
}

Forest economists have had a checkered history in showing their relevance to foresters in Canada. At the same time, foresters have sometimes seemed to ignore social considerations, identified by economists, in practices and policies. Although communication seems to be improving, there are still a number of divisive issues and associated viewpoints that inhibit the use of economics in forestry. In this paper, I investigate four hypotheses that could explain why forest economists and foresters in Canada have had such a hard time communicating. Hypothesis \#1 is that economic concepts are irrelevant to forestry. Hypothesis \#2 is that foresters are actually brilliant, but "dark side," economists that have structured systems to protect forests from economic forces. Hypothesis \#3 is that foresters are "enlightened" economists that are catering to real social preferences that most economists do not understand. Hypothesis \#4 is that forest economics may be relevant but is difficult within the contexts that it is practised. Analysis shows that while all hypotheses have elements of truth, the higher numbered hypotheses tend to be more supportable.

Key Words: relevance of forest economics, forest management, forest policy, social forestry, sustained yield

Les économistes forestiers ont tenté à maintes reprises de démontrer leur importance aux forestiers du Canada. Au même moment, les forestiers ont parfois semblé ignorer les aspects sociaux, pointés par les économistes, dans leurs pratiques et leurs politiques. Même si les communications semblent s'être améliorées, il existe encore un certain nombre d'enjeux sources de conflits et associés aux points de vue qui limitent l'utilisation des principes économiques en foresterie. Dans cet article, j'aborde quatre hypothèses qui pourraient expliquer pourquoi les économistes forestiers et les forestiers au Canada ont connu tant de moments difficiles dans leurs communications. La première hypothèse est que les concepts économiques sont non pertinents en foresterie. La seconde hypothèse est que les forestiers sont brillants, mais que les économistes « issus des forces obscures » ont des systèmes structurés pour protéger les forêts contre les forces économiques. La troisième hypothèse veut que les forestiers soient des économistes « éclairés » qui recueillent les préférences sociales réelles que la plupart des économistes ne comprennent pas. La quatrième hypothèse considère que l'économie forestière pourrait être pertinente selon le contexte en vigueur. L'analyse démontre que même si toutes ces hypothèses contiennent un élément de vérité, les dernières tendent à être plus près de la vérité.

Mots-clés : pertinence de l'économie forestière, aménagement forestier, politiques forestières, foresterie sociale, rendement soutenu

\section{Introduction}

Warning: The following paper contains half-truths, sarcasm, innuendo, hyperbole, and unsubstantiated opinions. Although this style is somewhat unorthodox, it is intended to present and provoke a wide range of ideas. This paper is not meant to be taken literally, but it is hoped that this method of presentation will stimulate interest and allow readers to chose amongst presented ideas in order to establish their own boundaries between "truths" and "fictions."

When I first began graduate studies in forestry economics at the University of British Columbia in 1983, I was astonished to discover that foresters had less than full respect for my newly chosen profession. Indeed, I began to wonder what role a forest economist could have in influencing forest policies given what foresters seemed to think of forestry economics. Hence, much of my graduate education, and time spent since then, has been devoted to trying to understand the sources of this conflict.

${ }^{1}$ Based on a presentation at the conference, "Social and Economic Perspectives of Boreal Forest Ecosystem Management," Edinburgh Scotland, June $5-8,2001$.

${ }^{2}$ Professor, Forest Economics and Policy, Department of Rural Economy, University of Alberta, Edmonton, AB T6G 2H1. E-mail: marty.luckert@ualberta.ca
I was reminded again of many of these thoughts as I read the exchanges between McKenney (2000a) and Baskerville (2000). ${ }^{3}$

How can it be that after almost 20 years, these same points are being argued? ${ }^{4}$ Below I develop four hypotheses regarding sources of conflicts between foresters and forest economists that may have influenced the role that economics has played in forest management

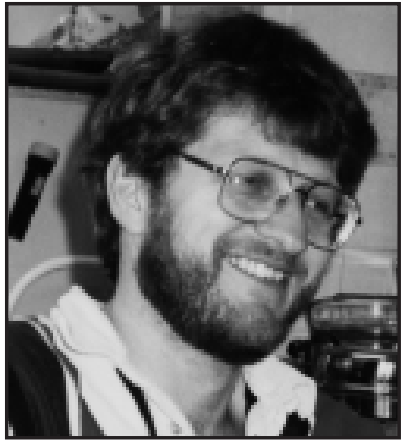

M.K. (Marty) Luckert and policy. A common theme among these hypotheses is a healthy

\footnotetext{
${ }^{3}$ Much of the debate amongst foresters and economists has not taken place in journals, with some notable exceptions that are used in this paper. Rather, much has been discussed in conversations at conferences, hallways, and bars. Accordingly, there is not a good written record of these debates and I must therefore rely heavily on personal experiences to generalize the essence of these debates. Therefore, many of the arguments presented below, unfortunately, cannot be substantiated with sources.

${ }^{4}$ Although these arguments have, in my limited experience, persisted for the last 20 years, I suspect that others with a longer institutional memory would say these issues have persisted for much longer periods. Also, as one reviewer pointed out, these types of persistent debates are not unusual in situations where disciplines have overlapping interests.
} 
respect for foresters. In a recent essay, Roughgarden (2001), an ecologist who spent much time working with economists, discusses five rules to follow in a "Guide to Diplomatic Relations With Economists." One of those rules is "don't underestimate them." It is in the spirit of this advice, with respect to foresters, that the following thoughts are presented.

To investigate the role of economics in Canadian Forestry, I will consider four different hypotheses. The first hypothesis is that economic concepts are irrelevant to forestry. Economists have heard many variants of this argued by foresters, some of which will be presented below. The second hypothesis is that economic concepts have been used by foresters, who are actually "dark side" economists. As such, their motives are not to further social values, but instead to push their own agendas, which involve growing trees at any cost. The third hypothesis to be investigated is similar to the second hypothesis, in that foresters are thought to use economic concepts, but are doing so from an enlightened perspective that, instead of promoting their own values, is actually a reflection of social values. The fourth and final hypothesis to be considered is that given the setting in which Canadian forestry is practised, economic concepts can be difficult to make relevant to practised forestry.

\section{Hypothesis \#1: Economic Concepts Are Irrele- vant To Forestry}

As economists and foresters have continued their debates, foresters have adopted a number of themes in their questioning of economic concepts. These themes include: "replace what we take"; "interest rates are an irrelevant invention of economists"; "financial analysis at the stand level is irrelevant"; "Faustmann is irrelevant"; "sustained yield is sacred"; and, finally, "sustained yield is an outdated economic paradigm." Each of these is considered below in turn.

\section{Replace what we take}

Long before "The Lion King," foresters frequently viewed forests as a continuous circle of life without beginning or end. Mature trees are followed by dying trees, which are replaced by new trees that grow into mature trees. The forester's role is to enter into this circle, usually with harvesting and regeneration efforts, while making sure that the circle continues. As part of this thinking, considerations of costs and benefits of forestry activities could be undertaken in several ways. For example, when considering the continuous circular flow, benefits from harvesting mature trees could be considered relative to costs of replacement, or costs of replacement could be considered relative to future benefits created (e.g., Reed and Baskerville 1989).

However, the choice of which accounting stance to take seems to form along disciplinary lines. Foresters advocate counting costs of regeneration against harvests of currently mature timber, while economists argue that current costs should be counted against future crops created with those expenditures. From a forester's perspective, the choice between these two options was philosophical, arguing that we must replace what we take. In contrast, the economic logic rests on the economic principle of marginal analysis. When deciding to harvest a forest stand, all future benefits and costs should be considered. Similarly, when deciding on a regeneration treatment, all future benefits and costs should be considered. Therefore, the relevant considerations are dictated by where the analysis in time is taking place. After a stand is harvested, the benefits received are considered "sunk" and therefore do not enter into marginal analysis. In order to maximize returns to future endeavours, it is important to consider additional benefits and costs from where we are now, for alternative future paths.

A frequent response by foresters to the economic call for marginal analysis is that we must replace what we take. This philosophy was sometimes referred to as a conservation ethic that is associated with sustained yield policies designed to support community stability and provide for the livelihoods of future generations (e.g., Reed and Baskerville 1989). ${ }^{5}$ It is argued that we have an obligation to future generations to continue the forest circle of life, as it was given to us. Therefore, financial analysis of alternative regeneration strategies is irrelevant. We continue forests for future generations, not for financial considerations.

The economist's response is that replacing what we take is not necessarily looking after future generations. True forward-looking planning requires that we think about the values associated with the future forest that we are trying to create. Although replacing forests within a sustained yield framework does have an implicit desired structure of future forests (i.e., a normal forest), such future structures have not been explicitly connected with what society may desire. Therefore, replacing what we take is not good enough. Future forests must be more explicitly connected with social objectives.

Furthermore, in pursuit of creating forests that reflect social objectives, we are unfortunately not given a blank check. Society has a number of options in which it may invest with limited funds, including infrastructure, new technology, and education for our kids. Along these lines, holding the amount of natural capital in forests constant, by merely replacing what we take, is not necessarily ideal for society. More, less or changing amounts of capital in forests could better facilitate social objectives. Although there may be social benefits associated with the idea of "replace what we take," there may also be social costs associated with this approach. Insufficient investment will result in forgone returns within the forestry sector, while over-investment will result in forgone returns in other parts of the economy. Forestry, therefore, should not be immune from financial and other social considerations present in a broad economic context.

Economic arguments have also been put forward which claim that, rather than a conservation ethic, it is the institutional structure of forestry that is causing forestry firms to count current costs of regeneration against current benefits of harvest (Luckert and Haley 1993). Within the context of Canadian forest tenures, the absence of clear rights to future forests means that reforestation may be done to fulfil requirements so that current harvests may continue. Therefore, regeneration costs may be counted against current harvests because forest tenures do not confer sufficient rights to future benefit streams. To an economist, it may seem strange that the results of these incentives have been interpreted as being a conservation ethic.

\section{Interest rates are an irrelevant invention of economists}

The consequences of a forward-looking accounting stance within the "forest circle of life," and of looking beyond

\footnotetext{
$\overline{{ }^{5} \text { Such conservation ethics are not unique to foresters. Resource economists }}$ have long been grappling with concepts of wise use within the context of an uncertain future.
} 
"replacing what we take," are significant within the context of forestry investment decisions. If costs are weighed against future benefits, rather than past benefits, then future benefits may be discounted, thereby making it difficult to justify expenditures in new forests. The response of foresters has been to link economists with a desire to short-change future generations because using discount rates in analyses makes future benefits count less than they should.

The response of economists has been to point out that interest rates are not the invention of economists. Interest rates are the result of markets that indicate that we as a society place a cost on delaying consumption and/or forgoing interest that could be earned elsewhere by invested capital. Accordingly, it is not economists that make interest rates relevant, but markets that present us with real opportunity costs of using capital in one place rather than another.

\section{Financial analysis at the stand-level is irrelevant}

In discussions between foresters and economists, it is sometimes conceded that financial analysis may be needed, but that financial analysis at the stand level is irrelevant (e.g., Reed and Baskerville 1989). Foresters don't manage stands, it is argued, they manage complete forests. Therefore, a more holistic view is needed than the stand-level financial analyses that economists sometimes conduct (Baskerville 2000).

The economist's reply is that, despite the fact that foresters manage whole forests, stand-level analyses are relevant (Hegan and Luckert 2000). Stands make up crucial building blocks that are aggregated up into forests. However, financial analyses at the stand level do not simply extrapolate up to the forest level. The financial picture at the stand level may look markedly different to that at the forest level, as benefit streams from investments are altered by forest-level harvesting constraints and associated processes such as the Allowable Cut Effect (ACE). However, it is still valuable to know what finances look like at the stand level. For example, when stand-level financial analyses show returns to be highly negative, and forest-level analyses show positive returns, we have a better understanding of the impacts of placing forest-level harvesting constraints on management decisions. If the underlying stand-level finances are suspect, we should also be suspect of the forest-level constraints that somehow magically make investments profitable. Accordingly, looking at stand-level results allows us to question whether some of these forest-level constraints are worth the costs, and whether they are creating incentives that are desirable. ${ }^{6}$

\section{Faustmann is irrelevant}

The argument that Faustmann is of limited relevance (Reed and Baskerville 1989), or irrelevant, is viewed by economists as really hitting below the belt. Faustmann is thought by many to be the father of forest economics. ${ }^{7}$ Therefore, to economists, calling Faustmann irrelevant is somewhat akin to calling Gifford Pinchot irrelevant to forestry. Faustmann (1849) realized that the value of forest land is derived from the benefits that it can produce in excess of costs over an infinite time stream. He further showed how benefits and costs from forest lands were

\footnotetext{
${ }^{6}$ See Luckert (2001) for a discussion of welfare implications of the ACE. ${ }^{7}$ In a recent issue of Forest Science, Brazee (2001) guest edits a series of articles devoted to the contribution of Faustmann to forest economics.
}

heavily influenced by the choice of when to harvest mature trees, and that there were frequently unique solutions that would maximize the value of forest land. These solutions, that maximize values of forest lands, refer to what economists call the "optimum economic rotation," and are a fundamental concept in the theory of timber supply.

McKenney (2000a) in his response to Reed and Baskerville (1989) admirably defends the general notion, that although many of the specific original assumptions of the Faustmann (1849) model do not apply to the situation in Canada, the fundamental concepts are sound and may be made applicable, frequently with minor arithmetic adjustments.

\section{Sustained yield is sacred}

The forester's justification for sustained yield policies generally revolves around two points. First, it is argued that sustained yield of timber is required for the sustainability of the many forest-dependent communities in rural areas (e.g., Le Master and Beuter 1989). Second, it is argued that if we sustain the production of trees, we will also sustain the multiple forest values that are associated with growing trees (e.g., Pearse 1990).

Economists have a long history of criticizing sustained yield policies (e.g., Walker 1977). Regarding stability of communities, economists have argued that by regulating the flow of timber harvested, we may actually destabilize economies (e.g., Dowdle 1984). Destabilization happens when the quantity supplied cannot adequately respond to changes in demands for timber. ${ }^{8}$ For example, when the demand for timber and prices are high, the inability to increase the quantity supplied because of sustained yield constraints can cause prices to rise even higher. Likewise, when the demand for timber and prices are low, the inability to decrease the quantity supplied because of sustained yield constraints can cause prices to drop even lower. Therefore, by removing, or reducing, the price elasticity from the supply of timber, sustained yield can exacerbate instability caused by market fluctuations.

Not only may sustained yield policies destabilize economies, but they may do so at a high cost (e.g., Boyd and Hyde 1989). Some of the costs of sustained yield are associated with not changing harvests in response to changing prices. Therefore, in cases where demand is low, firms may be forced to harvest at lower than market prices, with higher than market costs.

The focus of sustained yield on timber volumes has also been criticized (e.g., Haley and Luckert 1995). Indeed, the fall of sustained yield, and the rise of alternative paradigms, such as sustainable forest management, suggests that it is more than just economists who are no longer satisfied with assuming that continuously producing timber will look after other forest resources. Instead, it is thought to be necessary to consider explicitly what might be done for non-timber resources.

\footnotetext{
${ }^{8}$ Although in practice, most sustained yield policies do allow some deviation from AACs, to the extent that AACs are at all binding, the results of this literature hold. Consequences are commensurate to the degree that harvesting is constrained by sustained yield.

${ }^{9}$ Although many foresters still seem to cling to the link between sustained yield and stability, they seem to be more receptive to ideas that non-timber resources need special attention. Along these lines, sustained yield is still often viewed as being a necessary but not sufficient condition for Sustainable Forest Management.
} 


\section{Sustained yield is an outdated economic paradigm}

The above description of foresters' view of sustained yield is now somewhat dated. Many foresters now seem to agree that paradigms other than sustained yield may be needed to address societal concerns. ${ }^{9}$ Along this vein, one of the sentiments expressed has been, "We're finally getting rid of that economic paradigm of Sustained Yield, where we try to preserve the capital (i.e., the growing stock), and harvest only the interest (i.e., the growth)." Given the above summary description of the economic critiques of sustained yield, it is understandable why economists tend to stand in utter disbelief in the presence of such statements.

\section{Summary of Hypothesis \#1}

The above dialogues suggest that economists may have been successful in winning a number of the battles in which their work is claimed to be irrelevant. Although this may be the case, have economists won battles, only to lose the war? Who have they convinced with such arguments? What influence have economists had in Canadian forest policy? As McKenney (2000b) points out, the number of forest economists in Canada is quite low. Furthermore, with little representation in provincial governments and industry, they are largely restricted to academia and federal governments. Accordingly, they have historically had very little to do with policy making. ${ }^{10}$

Because of the minimal influence that forest economists have had, despite individual battles that they may have won, it may behoove us to consider other hypotheses. As a result of the debates presented above, economists frequently assume that foresters simply do not understand economics, likely because they don't want to. By dismissing economics as irrelevant, foresters are free from the perils of economic scrutiny, and are able to justify forest investments and a continuous flow of timber from their self-created moral high ground. However, in the spirit of "don't underestimate them," I propose further hypotheses meant to investigate two questions: 1) are foresters really ignorant of economics, or have they cleverly used economics to further their purposes?; 2) are foresters really promoting their own values, or are they reflecting and furthering social objectives?

\section{Hypothesis \#2: Foresters Are Actually "Dark Side" Economists, Protecting Forests}

The second hypothesis considers that although foresters may be pursuing their own values, they may not be ignorant of economics. Rather, it is possible that foresters have cleverly learned and used economics to devise a system that would allow them to pursue their agendas. Thus, rather than being traditional economists, who search for ways of directing market forces towards social objectives, foresters are actually dark side economists who are directing market forces so that the sustained production of trees is perpetuated at any cost.

The underlying premise of foresters that could drive such a situation is simple. Forests are good, but economists and mar-

\footnotetext{
${ }^{10}$ This trend seems to have changed markedly over the last few years, as there seem to be increasing demands for services of forest and natural resource economists.

${ }^{11}$ An opportunity cost is the value of the next best alternative to the option being undertaken. In economics opportunity costs are used to assess whether the option being pursued is better than the next best option.
}

kets do not recognize this. Following this premise is a strategy that is as ingenious as it is sinister. The strategy involves designing a system where values are so distorted that they cannot face their true opportunity costs. ${ }^{11}$ Furthermore, the system can be made so complex that economic analysis becomes almost impossible to make relevant. Then, free from the scrutiny of economics, forestry activities may proceed unhindered.

To pursue this strategy, there were a number of required steps. First, in order to create a system to promote forestry and silence economists, foresters would have to learn economics. The underlying logic is that you must know your enemies in order to defeat them. Next, foresters would need to design a system that would justify forestry. Sustained yield emerged ${ }^{12}$, as it could be morally justified with concepts of "the circle of life" and "replace what we take." Sustained yield had to be made operational in some way, so Annual Allowable Cuts (AACs) were created. As discussed above, these AACs served to obscure the relevance of stand-level financial analyses, shifting the focus to forest-level results. Similarly, with attention shifted to forest-level planning, the relevance of optimal economic rotations derived at the stand level became less apparent.

But, it was not enough to just confuse economists. Financial accountability could infiltrate from markets too, as owners of forest resources could consider how to spend scarce resources for future returns. So, a subsequent step was to make rights to future forests hazy, by not granting private property rights to Canadian forests. With rights to future forests hazy, forest companies would not have incentives to consider finances of forestry investments. Instead, command and control systems would dominate, where costs are generally minimized, and not considered as an investment (e.g., Luckert 1998). Finally, if financial analysis did start to creep in, despite all of these barriers, the Allowable Cut Effect (ACE) can be used to facilitate expenditures in forestry. The ACE allows for " ... an increase in allowable annual cuts due to an increase in future productivity" (Schweitzer et. al 1972). ${ }^{13}$ Accordingly, immediate benefits may be had in return for investments in forest management, potentially making forestry practices much more profitable.

Although the conspiracy theory above seems far-fetched, the evidence is compelling. How else, but by design, could such an ingenious system be constructed to confound economic analysis and promote and protect timber volumes. Furthermore, the success of the system has been phenomenal. Despite the fact that concepts of sustained yield are now finally under siege, the paradigm has lasted for generations and has spanned continents. Furthermore, private rights to future forests are still hazy across Canada.

However, an alternative interpretation of the above is that instead of being dark side economists, foresters are actually savvy, enlightened economists that have created policies to further social objectives.

\footnotetext{
${ }^{12}$ It is interesting to note that both the origins of sustained yield and the Faustmann origins of forestry economics came from Europe. Conspiracy by dark side economists or coincidence?

${ }^{13}$ The ACE is a particularly ingenious part of this conspiracy. Despite the fact that ACE policies have been implicit to sustained yield policies since their origin, the ACE remained hidden to non-foresters, and was not even investigated by economists till the 1960 s and 1970s (e.g. Pearse 1965, Schweitzer et al. 1972).
} 


\section{Hypothesis \#3: Foresters Are "Enlightened" Economists Catering To Social Preferences}

The underlying premise that could drive the approach in Hypothesis 3 is slightly different from that of hypothesis 2 . Enlightened foresters would recognize that markets fail with respect to providing forest resources and could claim that they have been protecting forests from these failures in order to give society what it wants. This is necessary, because economists have failed in their efforts to reflect social preferences, and have not understood the relevance of current institutional structures. Therefore, if economists and markets can't provide a policy structure to provide what society obviously wants, foresters could ignore economics and protect forests themselves.

In response to this problem, the same steps as highlighted above were taken. ${ }^{14}$ Sustained yield was adopted, and rights to future forests operating on Crown lands were made hazy. Somewhat ironically, evidence to support this hypothesis has come from a number of economic studies. Binkley (1980) hypothesized long ago that sustaining timber volumes is an important part of social objectives. Indeed, more recent empirical evidence suggests that the creation of constant timber volumes from forests may be highly desired by society (Luckert and Adamovicz 1993, Taylor 1999). Furthermore, with time, economists have increasingly questioned concepts surrounding the social rate of discount for forestry (e.g., Price 1993). Economists have also started to investigate differences between stand-level and forest-level results in the areas of financial analyses of silviculture (e.g., Hegan and Luckert 2000), and the optimum economic rotation (e.g., Chang 1990; Howard 1990; Oderwald and Duerr 1990a, b; Hoganson and McDill 1993).

Despite the fact that there is some evidence to suggest that foresters may have been correct in their assessment of what society wants, two points suggest that economists may also have been correct in their criticisms.

First, one must wonder whether the forest policy system was designed to reflect or create social values. That is, what came first, the sustained yield/tenure system or social values? If the system created the social values, then we are back to an extremely successful "dark side" economist strategy as outlined in Hypothesis \#2. That is, the system was so clever, that it was able to make society change what it believes and values. If, instead, the system was created to facilitate social values, then we are back to Hypothesis \#3, where foresters are acting as enlightened economists.

Second, there are a number of areas where claims of economists seem to have been vindicated. Society seems less willing to simply have us "replace what we take" in the "forestry circle of life." Instead, foresters have had to increasingly consider social attributes of "desired future forests," which necessitates decisions about alternative input and output possibilities with financial consequences. Furthermore, sustained yield is slowly dying. Many of the early economic criticisms of sustained yield are being voiced by a much wider audience, and alternative paradigms, such as sustainable forest management, have emerged.

\footnotetext{
${ }^{14}$ Despite the fact that I might be able to distort logic and interpretations to create alternative hypotheses, I am unable to change basic historical happenings.
}

\section{Hypothesis \#4: Economic Concepts Can Be Difficult To Make Relevant To Practised Forestry}

The fourth hypothesis emerges from looking at the evidence for Hypothesis \#3. The fact that the forest economics literature is evolving to deal with many of the complexities posed by foresters and current policy systems suggests that there have been historic difficulties in making analyses relevant. As more has been learned in economics, we have found that values and preferences regarding forest resources are perhaps more complicated than originally thought, and are difficult to identify and measure. The problem involves having to consider welfare implications of forest management practices among groups in society who hold very different values. Such analyses are difficult enough when considering the welfare of those present today, and become even more challenging when considering welfare impacts of management decisions that span generations. Furthermore, these values exist within the context of complex sustained yield and tenure policies, which bend and twist values in unsuspecting, and sometimes unknown, ways. As indicated by the literature sited under Hypothesis \#3, it has taken economists some time to begin sorting through these problems, to get to a point to where they could be of more relevance.

\section{Conclusions}

By way of concluding, I will start by returning to the four hypotheses that are considered in this paper.

\section{Hypothesis \#1: Economic concepts are irrelevant to forestry}

This hypothesis, I must reject. Although attacks on economists have been numerous and widespread, economists have persisted and are increasingly being demanded for their input on forest policy matters. Nonetheless, economic analyses could be more relevant if they were conducted with more consideration to complications of values and preferences within the sustained yield/tenure framework of Canada.

\section{Hypothesis \#2: Foresters are actually "dark side" economists, protecting forests}

I am inconclusive regarding this hypothesis. Although conspiracy theories may be the result of tormented and confused minds (traits found frequently in this author), the logic is compelling. How else could a system like we have come about, except by the design of very clever people? Even if there has not been an overt conspiracy, I do believe that foresters have attempted to act on behalf of society, while sometimes assuming that their personal values towards forests are also best for society. I also believe that foresters have been extremely successful in "protecting" forests with policies and practice, sometimes at great cost to society.

\section{Hypothesis \#3: Foresters are "enlightened" economists catering to social preferences}

I am also inconclusive with respect to this hypothesis. Although evidence suggests that some policies and practices of foresters do further social objectives, there is also evidence in recent changes to suggest that economists were correct. That is, forestry has not been practised with sufficient knowledge about whether policies and practices are best furthering social objectives. 


\section{Hypothesis \#4: Economic concepts can be difficult to make relevant to practised forestry}

This hypothesis I accept. History shows that earlier economic analyses were not completely relevant, and that more knowledge has lead to recognizing increasing complexity in dealing with economic forestry issues in Canada. Although it has taken quite a while, economists are increasingly wading into the complex values and institutional structures of Canadian forestry. Although there is still a long way to go, increased demands for forest economists indicate that progress is being made. Besides, if this hypothesis were false, economists would be even more relevant, and I would not be writing this paper.

Despite my tongue-in-cheek analysis of the hypotheses above, I believe there are elements of truth in all four. The complexity of values associated with forests has hindered the relevance of economics, and has lead foresters to create policies that have in some ways furthered social objectives, but in other ways, allowed them to pursue their personal values without much information about what might be better for society. As economists get better at showing the implications of alternative management practices for social objectives, we will hopefully continue to increase social considerations in our forestry practices.

\section{Acknowledgements}

Thanks to Gordon Weetman and two anonymous referees for their comments. Also, thanks to the Sustainable Forest Management Network for research support.

\section{References}

Baskerville, G. 2000. Canadian Forest Management. Letter. For. Chron. (76) $4: 531$.

Binkley, C.S. 1980. Economic Analysis of the Allowable Cut Effect. For. Sci. 26: 633-642.

Boyd, R.G. and W.F. Hyde. 1989. Forest Sector Intervention: The Impacts of Regulation on Social Welfare. Iowa State University Press, Ames, Iowa. 295 p.

Brazee, R.J. 2001. Introduction - The Faustmann Formula: Fundamental to forest Economics 150 Years After Publication. For. Sci. 47(4): 441-442.

Chang, S.J. 1990. Comment on Discussion Paper: Konig-Faustmannism: A Critique. For. Sci. 36: 177-179.

Dowdle, B. 1984. The Case for Selling Federal Timber Lands. In Selling the Federal Forests. A.E. Gamache (ed.). pp. 21-46. University of Washington.

Faustmann, M. 1849. On the Determination of the Value Which Forest Land and Immature Stands Possess for Forestry. English edition. In M. Gane (ed.). 1968. Martin Faustmann and the Evolution of Discounted Cash Flow. Institute Paper 42. Commonwealth Forestry Institute, Oxford University.

Haley, D. and M.K. Luckert. 1995. Policy Instruments for Sustainable Development in the British Columbia Forestry Sector. In A.D. Scott and D. Cohen (eds.). Institutions For Sustainable Development in Natural Resources in British Columbia. pp. 54-79. UBC Press, Vancouver, BC.
Hegan, L. and M.K. Luckert. 2000. An economic assessment of the allowable cut effect (ACE) for enhanced forest management policies: an Alberta case study. Can. J. For. Res. 30(10): 1591-1600.

Hoganson, H. M. and M. McDill. 1993. More on Forest Regulation: an LP Perspective. For. Sci. 39: 321-347.

Howard, T.E. 1990. Comment on Discussion Paper: Konig-Faustmannism: A Critique. For. Sci. 36: 175-176.

Le master, D.C. and J.H. Beuter (eds.). 1989. Community Stability and Forest-Based Economies. Proceedings of a conference in Portland Oregon, November 16-18, 1987. Timber Press, Portland, Oregon.

Luckert, M.K. 1998. Efficiency Implications of Silvicultural Expenditures From Separating Ownership and Management on Forest Lands. For. Sci. 44(3): 365-378.

Luckert, M.K. 2001. Welfare Implications of the Allowable Cut Effect in the Context of Sustained Yield and Sustainable Development Forestry. Journal of Forest Economics 7(3): 203-224.

Luckert, M.K. and D. Haley. 1993. Canadian Forest Tenures and the Silvicultural Investment Behavior of Rational Firms." Can. J. For. Res. 23: 1060-1064.

Luckert, M.K. and W.L. Adamowicz. 1993. Empirical Measures of Factors Affecting Social Rates of Discount. Environmental and Resource Economics. 3(1): 1-22. Also appears in W.L. Adamowicz, W. White and W.E. Phillips (eds.). Forestry and the Environment: Economic Perspectives. pp. 262-281. CAB International, Oxon.

McKenney, D. 2000a. What's the economics of intensive silviculture? For. Chron. (76) 2: 275-281.

McKenney, D. 2000b. Economics and Canadian Forest Management. Letter. For. Chron. (76) 6: 818-819.

Oderwald, R.G. and W.A. Duerr. 1990a. Konig-Faustmann: A Critique. Forest Science 36: 169-174.

Oderwald, R.G. and W.A. Duerr. 1990b. Discussion Paper Response to Comments on: Konig-Faustmannism: A Critique. For. Sci. 36: 185.

Pearse, P.H. 1965. Distortions in the market for forest land. For. Chron. 41: 406-418.

Pearse, P.H. 1990. Introduction to Forestry Economics. University of British Columbia Press: Vancouver, BC.

Price, C. 1993. Time, Discounting and Value. Blackwell Press, Oxford.

Reed, F.L.C. and G.L. Baskerville. 1989. A contemporary perspective on silviculture investments. Journal of Business Administration. (19) 1\&2: 161-185.

Roughgarden, J. 2001. Guide to Diplomatic Relations with Economists. Commentary. Bulletin of the Ecological Society of America. Jan.: 85-88.

Schweitzer, D.L.R., R.W. Sassaman and C.H. Schallau. 1972. Allowable cut effect: some physical and economic implications. J. For. 70: 415-418.

Taylor, C. 1999. Individual Time Preference in Forest Management. M.Sc. Thesis. Department of Rural Economy, University of Alberta. $119 \mathrm{p}$.

Walker, J.L. 1977. Economic efficiency and the National Forest Act of 1976. J. For. 75: 715-718. 